\title{
SPRAWOZDANIE Z PIERWSZEGO ŚWIATOWEGO KONGRESU AGROTURYSTYKI BOLZANO, WŁOCHY, 7-9 LISTOPADA 2018 ROKU
}

W dniach 7-9 listopada 2018 r. w Bolzano (Bozen) we Włoszech odbył się Pierwszy Światowy Kongres Agroturystyki. Został zorganizowany przez centrum badawcze Eurac Research, które ma siedzibę w Bolzano. Eurac Research zostało założone w 1992 r. jako stowarzyszenie zajmujące się m.in. prowadzeniem badań dotyczących prawa, mniejszości narodowych oraz regionów autonomicznych, a także środowiska alpejskiego. Stowarzyszenie stopniowo rozszerzało swoje działania na nowe obszary badawcze, przyciągając naukowców z całego świata, oraz wprowadzało nowe struktury jego funkcjonowania. Obecnie skupia niemal 400 badaczy pochodzących z ponad 25 krajów i reprezentujących różne dziedziny nauki (zob. Eurac Research). Eurac Research szuka rozwiązań w interakcji między wieloma zróżnicowanymi dyscyplinami nauki. Trzy główne tematy, którym poświęcone są prace badawcze realizowane obecnie $\mathrm{w}$ centrum, to: regiony, w których panują warunki korzystne do zamieszkania, różnorodność jako element poprawiający jakość życia ludzi oraz zdrowe społeczeństwo. W 2018 r. Eurac Research po raz pierwszy podjęło się organizacji na światową skalę kongresu poświęconego agroturystyce.

Wybór miejsca, w którym odbył się Światowy Kongres Agroturystyki nie był przypadkowy. Bolzano jest stolicą Tyrolu Południowego, znajdującego się $\mathrm{w}$ autonomicznym regionie Alto Adige (Górnej Adygi) graniczącym z Austrią. Turystyka jest tu ważnym sektorem gospodarczym, generuje ok. 11\% PKB. Zapewnia zatrudnienie na wsi i stała się alternatywnym źródłem dochodów, przyczyniając się do rozwoju przedsiębiorczości na 
tych obszarach. Obecnie ok. 2800 gospodarstw rolnych, z łącznej liczby $20000 \mathrm{w}$ tym regionie, oferuje usługi turystyczne. Jest to znaczący wskaźnik dla Tyrolu Południowego, który pod tym względem wypada korzystnie $\mathrm{w}$ porównaniu $\mathrm{z}$ innymi regionami Włoch. W Tyrolu Południowym dostępny jest szeroki wachlarz ofert turystycznych wysokiej jakości, na co wpływ ma m.in. lokalna marka Roter Hahn (Czerwony Kogut). Funkcjonuje ona od 1998 r. na rzecz utrzymania gwarancji jakości oferowanego produktu turystycznego, co uzyskuje poprzez stosowanie surowych i transparentnych kryteriów oceny oraz przeprowadzanie regularnych kontroli. Celem marki Roter Hahn jest promocja agroturystyki, także wiejskich gospód, wysokiej jakości produktów rolnych i rzemiosła, oferowanych w południowotyrolskich gospodarstwach. Organizatorzy marki odnoszą sukces, a Roter Hahn budzi zainteresowanie na świecie i może być stawiany za wzór do naśladowania (zob. Roter Hahn).

Cele Pierwszego Światowego Kongresu Agroturystyki były następujące:

- omówienie stosowanych na świecie rozwiązań w zakresie rozwoju turystyki wiejskiej, zwłaszcza najnowszych oraz najnowocześniejszych;

- wypracowanie definicji agroturystyki, wspólnie uzgodnionej w kontekście międzynarodowym;

- zbudowanie platformy networkingowej dla naukowców i praktyków zajmujących się agroturystyką;

- promowanie agroturystyki w sposób jednoznaczny, jako szczególnego rodzaju turystyki na obszarach wiejskich.

W wydarzeniu wzięło udział ponad 200 osób z 42 krajów, nie tylko z Europy, ale także z Australii, Azji, Afryki oraz Ameryki Północnej i Południowej (rys. 1).

Kongres otworzył dr Thomas Streifeneder, kierownik Instytutu Rozwoju Regionalnego w Eurac Research. Po przywitaniu uczestników oraz przedstawieniu osób zaangażowanych w organizację tego światowego wydarzenia, rozpoczął pierwszą sesję referatem wprowadzającym. Podjął temat roli i znaczenia agroturystyki. Nie pominął kwestii braku jednoznacznej definicji agroturystyki oraz potrzeby określenia rodzajów działalności, które ją tworzą. Referent podkreślił, że w dużym stopniu panuje zgoda co do tego, że agroturystyka odnosi się do „działalności turystycznej związanej $\mathrm{z}$ rolnictwem i prowadzonej w gospodarstwie rolnym". Niemniej jednak zauważył, że istnieją nieporozumienia dotyczące granic pojmowania agroturystyki. Zauważył, że pojawia się ona i rozwija w wielu częściach świata, jednak towarzyszą jej różne podejścia organizacyjne, które niejednokrot- 


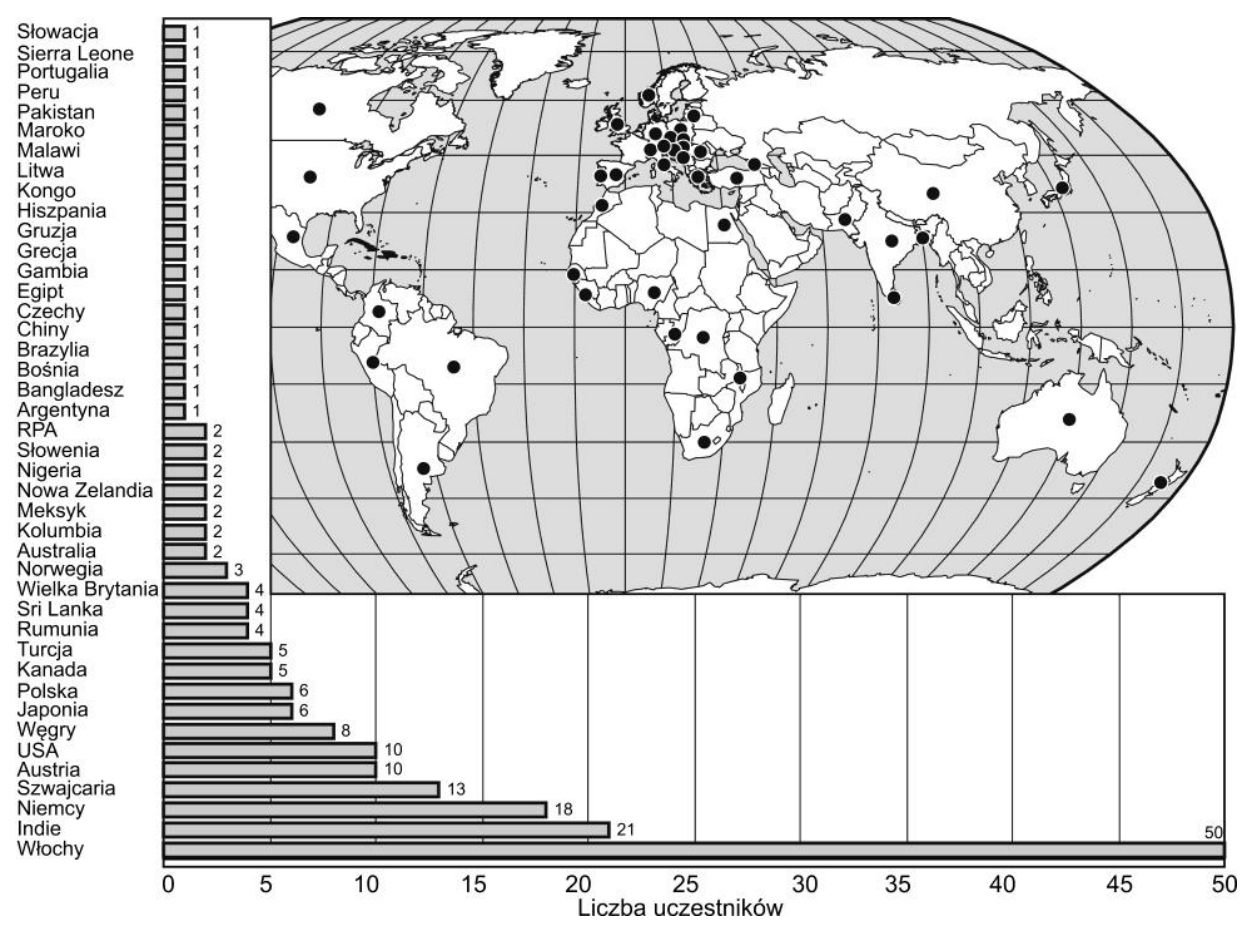

Rys. 1. Pochodzenie terytorialne uczestników

Pierwszego Światowego Kongresu Agroturystyki Źródło: prezentacja wprowadzająca Thomasa Streifenedera

nie stają na przeszkodzie pełnemu zrozumieniu jej znaczenia gospodarczego, a co za tym idzie - dostrzeżeniu potrzeby wspierania jej efektywności. Prelegent uznał, że do dokładnego zgłębienia zagadnień związanych $\mathrm{z}$ agroturystyką konieczny jest rzetelny oraz spójny pomiar tego zjawiska, dający podstawy do kształtowania odpowiednich programów wspierających rozwój gospodarstw rolnych i społeczności wiejskich.

Kongres w Bolzano został zapowiedziany jako przełomowy w historii turystyki na obszarach wiejskich. Podkreślono, że jest on uwieńczeniem wieloletnich działań prowadzonych na rzecz kreowania wizerunku obszarów wiejskich jako obfitujących w zróżnicowane i całoroczne atrakcje turystyczne. Podczas 3 dni trwania Kongresu zorganizowano 4 sesje plenarne, 15 sesji warsztatowych z ponad 50 referatami, sesję posterową oraz wizyty studyjne w kilku okolicznych gospodarstwach agroturystycznych. Omówiono liczne dobre praktyki i rozwiązania systemowe. Prelegenci dzielili się doświadczeniami m.in. z Włoch, Niemiec, Austrii, Grecji, Turcji, Rumunii, Nowej Zelandii, Egiptu, Republiki Południowej Afryki, Malawi, 
Japonii, Indii, Nepalu, Australii, USA, Kanady, Meksyku, Brazylii, Kolumbii, Polski oraz ze Sri Lanki. Szczegółowe informacje o przebiegu obrad, w tym prezentacje, zdjęcia oraz materiały video - są dostępne na stronie internetowej: http://agritourism.eurac.edu/editions/2018-edition/.

W pierwszym dniu Kongresu (7 listopada) sesję plenarną otworzył Herbert Dorfmann, członek Parlamentu Europejskiego, który przygotował wystąpienie pt. Agroturystyka w Europie: stan i perspektywy rozwoju. Referent podkreślił, że agroturystykę należy badać w kontekście bieżących wydarzeń społeczno-gospodarczych oraz przyszłych ram polityki Unii Europejskiej. Podczas ostatnich 20 lat $w$ europejskim sektorze rolnym dokonały się bowiem zauważalne zmiany strukturalne pokazujące, że gospodarstwa rodzinne i małe gospodarstwa rolne pełnią ważną funkcję na wielu płaszczyznach. Zwrócił on uwagę m.in. na kluczową rolę tych gospodarstw w zrównoważonym rozwoju turystyki, a zwłaszcza w kreowaniu ofert agroturystycznych. Prelegent zaznaczył, że w celu wzmocnienia sektora agroturystycznego $\mathrm{w}$ polityce europejskiej muszą zostać uwzględnione zmiany strukturalne zachodzące w rolnictwie. Stwierdził, że aby w przyszłości możliwe było jak najlepsze wspieranie tego sektora, należy położyć nacisk na regionalizm i krótkie łańcuchy kształtowania produktów agroturystycznych.

Następnie wystąpił Hans Embacher, dyrektor organizacji Farm Holidays Austria, z referatem pt. Agroturystyka i innowacyjność. Prelegent zaznaczył, że innowacyjność jest obecnie jedną z kluczowych kompetencji $\mathrm{w}$ turystyce, a potrzeba jej stałego rozwoju odnosi się nie tylko do produktu turystycznego, ale również do jego marketingu. Digitalizacja i silni międzynarodowi przedsiębiorcy to niektóre z czynników napędzających rozwój turystyki. Embacher podkreślił, że również konsument „zyskał siłę rynkową", ponieważ dzięki jego stałym opiniom/recenzjom rynek turystyki staje się coraz przejrzystszy. To z kolei stawia trudne wyzwania przed małymi i średnimi właścicielami gospodarstw agroturystycznych, którzy nie dysponują wystarczającymi zasobami kapitałowymi, jakie mogliby przeznaczyć na innowacyjne rozwiązania. Znajdują się oni w swego rodzaju pułapce - mają mniej wewnętrznych zasobów, które mogliby wykorzystać do wprowadzania innowacji, a zewnętrzni innowatorzy są skoncentrowani raczej na dużych przedsiębiorstwach. Małe gospodarstwa agroturystyczne mają jednak swoje mocne strony, do których można zaliczyć np. osobisty kontakt gospodarzy z klientem, możliwość bezpośredniego oferowania lokalnych produktów rolnych, prezentowania miejscowych tradycji itp. Obecnie istnieje zapotrzebowanie na te usługi, 
co daje duże szanse rozwojowe, jednakże aby utrzymać silną pozycję na rynku, gospodarstwa agroturystyczne muszą stawić czoła wyzwaniu, jakim jest innowacyjność.

Następnie uczestnicy wysłuchali wystąpienia pt. Rolnictwo i turystyka - powiazania oraz przykłady Christiana Fischera, profesora ekonomii żywności, zarządzania i marketingu na Wolnym Uniwersytecie w Bolzano. Prelegent podkreślił, że rolnictwo i turystyka są ze sobą powiązane gospodarczo. Łączą je takie zasoby, jak: ziemia i praca $\mathrm{w}$ gospodarstwie rolnym w zakresie produkcji żywności, udzielanie zakwaterowania turystom oraz zaspokajanie innych potrzeb gości poprzez dostarczanie im towarów i usług $\mathrm{w}$ trakcie ich pobytu oraz po nim. W referacie poruszono następujące zagadnienia: produkcja żywności i innych towarów w gospodarstwie rolnym przeznaczonych dla turystów podczas ich pobytu, eksport produktów rolnych do krajów pochodzenia turystów po zakończeniu wizyty, zakwaterowanie gości w gospodarstwie (agroturystyka), usługi uzupełniające (np. gospodarstwa rolne jako miejsca podziwiania krajobrazu) i inne formy działalności rolników związanej z turystyką (np. praca jako personel ośrodka narciarskiego, kierowcy autobusów itp.).

W pierwszym dniu Kongresu odbyły się również sesje warsztatowe, których tematykę przedstawiono $\mathrm{w}$ tab. 1.

Tab. 1. Sesje warsztatowe w pierwszym dniu Kongresu (7 listopada 2018 r.)

\begin{tabular}{|c|c|}
\hline Sesja warsztatowa & Wygłoszone referaty \\
\hline \multicolumn{2}{|r|}{ Sesje równoległe $\mathrm{nr} 1$} \\
\hline $\begin{array}{l}\text { Czynniki sprzyjajace działalności } \\
\text { agroturystycznej } \\
\text { Przewodnictwo: } \\
\text { Tor Arnesen, starszy pracow- } \\
\text { nik naukowy, Instytut Ba- } \\
\text { dawczy Norwegii Wschodniej } \\
\text { (ENRI), Norwegia }\end{array}$ & $\begin{array}{l}\text { 1. Definiowanie agroturystyki w kontekście innych form } \\
\text { turystyki wiejskiej rozwijanych na obszarach rolniczych } \\
\text { - Rohana P. Mahaliyanaarachchi, Uniwersytet Sa- } \\
\text { baragamuwa w Sri Lance, Sri Lanka } \\
\text { 2. Postrzeganie agroturystyki, wspótpraca i sieci agrotury- } \\
\text { styczne: przykłady empiryczne z Grecji - Sofia Karam- } \\
\text { pela, Uniwersytet Egejski, Grecja; George Papapanos } \\
\text { i Thanasis Kizos, Uniwersytet Egejski, Mytylena, } \\
\text { Grecja } \\
\text { 3. Agroturystyka w Południowym Tyrolu: analiza oparta } \\
\text { na ocenie czynników hedonistycznych - Katia Laura Si- } \\
\text { dali, Wolny Uniwersytet w Bozen (Bolzano), Włochy; } \\
\text { Günter Schamel, Wolny Uniwersytet w Bozen (Bol- } \\
\text { zano), Włochy } \\
\text { 4. Witalizowanie agroturystyki poprzez kulturę - Sabine } \\
\text { Zimmermann, Stefan Könneke, Magdalena Zim- } \\
\text { mermann, Netzwerk Kultur \& Heimat Hildeshei- } \\
\text { mer Land e.V., Niemcy }\end{array}$ \\
\hline
\end{tabular}


Tab. 1 (cd.)

\begin{tabular}{|c|c|}
\hline Sesja warsztatowa & Wygłoszone referaty \\
\hline \multicolumn{2}{|r|}{ Sesje równoległe $\mathrm{nr} 1$} \\
\hline $\begin{array}{l}\text { Wyzwania zwiazane z przedsię- } \\
\text { biorczościa: jak sobie poradzić ze } \\
\text { zrównoważonym rozwojem } \\
\text { Przewodnictwo: } \\
\text { prof. Christian Fischer, Wol- } \\
\text { ny Uniwersytet w Bolzano (Bo- } \\
\text { zen), Włochy }\end{array}$ & $\begin{array}{l}\text { 1. Czy agroturystyka jest siła napędowa zrównoważonego } \\
\text { rolnictwa? Przykłady z Włoch - Benedetto Rocchi, } \\
\text { Gianluca Stefani, Uniwersytet Florencki, Włochy; Edi } \\
\text { Defrancesco, Uniwersytet w Padwie, Włochy } \\
\text { 2. Przedsiębiorczość w agroturystyce w USA: kluczowe } \\
\text { czynniki sukcesu - Erin Johnson, Platte River Fort, USA } \\
\text { 3. Reżyserowanie wiejskiego życia: analiza mikroprzedsiębior- } \\
\text { ców agroturystycznych na obszarach wiejskich Bawarii } \\
\text { - Stefan Kordel, Uniwersytet Fryderyka i Aleksan- } \\
\text { dra w Erlangen i Norymberdze, Niemcy } \\
\text { 4. Od ośrodka turystycznego do ekoturystyki i agroturysty- } \\
\text { ki. Wyzwanie w Wadi el Gemal National Park w Egipcie } \\
\text { - Mahmoud Ismail Sharan i Johannes Girardi, Park } \\
\text { Narodowy Wadi el Gemal, Egipt }\end{array}$ \\
\hline $\begin{array}{l}\text { Stawianie czoła nowym wyzwa- } \\
\text { niom - nowe systemy rolnictwa, } \\
\text { strategie jakości i innowacje spo- } \\
\text { łeczne } \\
\text { Przewodnictwo: } \\
\text { prof. Emilio Chiodo, Univer- } \\
\text { sity of Teramo, Włochy; prof. } \\
\text { Rita Salvatore, Stowarzysze- } \\
\text { nie ISLE, Francja }\end{array}$ & $\begin{array}{l}\text { 1. Agroturystyka, nowe rolnictwo i innowacje społeczne } \\
\text { z perspektywy międzynarodowej. Doświadczenia i porów- } \\
\text { nania - R. David Lamie, Clemson University, USA, } \\
\text { Stowarzyszenie ISLE; Emilio Chiodo i Rita Salvato- } \\
\text { re, University of Teramo, Włochy; Corinne Stewart, } \\
\text { Stowarzyszenie ISLE, Francja; Jane Eastham, Har- } \\
\text { per Adams University, Wielka Brytania; Nidal Sha- } \\
\text { ban, Uniwersytet Leśnictwa, Sofia, Bułgaria } \\
\text { 2. Rola edukacji i szkoleń w agroturystyce: przypadek } \\
\text { regionu Emilia Romagna - Rino Ghelfi, Uniwersytet } \\
\text { Boloński, Włochy } \\
\text { 3. Agroturystyka, rolnictwo rodzinne i krótki tańcuch do- } \\
\text { staw żywności ekologicznej w Brazylii. Studium przypad- } \\
\text { ku „Acolhida na Colônia" - Emilio Chiodo i Andrea } \\
\text { Fantini, University of Teramo, Włochy; Oscar José } \\
\text { Rover, Universidade Federal de Santa Catarina, Bra- } \\
\text { zylia; Lucilene Assing, Associação Acolhida na Co- } \\
\text { lônia, SC, Brazylia } \\
\text { 4. Inicjatywy agroturystyczne w kontekście ciagłej migracji } \\
\text { zewnętrznej, analiza porównawcza Alp i chinskich regio- } \\
\text { nów górskich - Thomas Dax w imieniu Chen Yany- } \\
\text { ing, Uniwersytet Biji, Chiny } \\
\text { 5. Wptyw agroturystyki na żywotność gospodarstw rol- } \\
\text { nych. Przykłady z doliny Ötztal (Tyrol) - Rike Stotten, } \\
\text { Hannes Herrmann, Michaela Maurer, Uniwersytet } \\
\text { w Innsbrucku, Austria }\end{array}$ \\
\hline
\end{tabular}




\begin{tabular}{|c|c|}
\hline Sesja warsztatowa & Wygłoszone referaty \\
\hline \multicolumn{2}{|r|}{ Sesje równoległe $\mathrm{nr} 1$} \\
\hline $\begin{array}{l}\text { Wkład agroturystyki w przy- } \\
\text { szłość obszarów wiejskich } \\
\text { Przewodnictwo: } \\
\text { prof. Claudia Gil Arroyo, Uni- } \\
\text { wersytet Stanowy Karoliny Pół- } \\
\text { nocnej, USA }\end{array}$ & $\begin{array}{l}\text { 1. Ewolucja rumuńskiej agroturystyki i rola dotacji Unii Eu- } \\
\text { ropejskiej dla obszarów wiejskich - Nicola Galluzzo, } \\
\text { Associazione Studi Geografico-Economici delle Aree } \\
\text { Rurali, Włochy } \\
\text { 2. Możliwości rozwoju działalności agroturystycznej na ob- } \\
\text { szarach wiejskich w dolinie San Quintín, Kalifornia Dol- } \\
\text { na, Meksyk - Alma Lourdes Camacho, Autonomiczny } \\
\text { Uniwersytet Baja California, Meksyk } \\
\text { 3. Agroturystyka jako czynnik stymulujaccy, ale i utrudnia- } \\
\text { jący, oraz wzmacniający strategię dywersyfikacji obszarów } \\
\text { wiejskich: zróżnicowane przykłady ze Stowenii - Irma } \\
\text { Potocnik Slavic, Uniwersytet Lublański, Słowenia } \\
\text { 4. Rola płci w turystyce przedsiębranej przez społeczność lo- } \\
\text { kalna: idiosynkrazje oraz świadomość kulturowa rdzen- } \\
\text { nej społeczności w Peruwiańskich Andach - Claudia Gil } \\
\text { Arroyo, Uniwersytet Stanowy Karoliny Północnej, } \\
\text { USA; Sandra E. Sotomayor, Universidad San Igna- } \\
\text { cio de Loyola, Peru; Carla Barbieri, Uniwersytet Sta- } \\
\text { nowy Karoliny Północnej, USA; Whitney Knollenberg, } \\
\text { Uniwersytet Stanowy Karoliny Północnej, USA }\end{array}$ \\
\hline $\begin{array}{l}\text { Agroturystyka na świecie: podo- } \\
\text { bieństwa i różnice } \\
\text { Przewodnictwo: } \\
\text { Valentina Cattivelli, starszy } \\
\text { pracownik naukowy, Instytut } \\
\text { Rozwoju Regionalnego, Eurac } \\
\text { Research, Włochy }\end{array}$ & $\begin{array}{l}\text { 1. Rola kobiet w gospodarstwach agroturystycznych - Ma- } \\
\text { ria Anna Silbernagel Plunger, stowarzyszenie rolni- } \\
\text { ków Południowego Tyrolu, Włochy } \\
\text { 2. Koncepcja rozwoju agroturystyki w Bangladeszu: stu- } \\
\text { dium przypadku AIUB IRPDT - Abul Bashar Md } \\
\text { Rahmatullah, American International University, Ban- } \\
\text { gladesz } \\
\text { 3. Możliwości rozwoju agroturystyki w Izmirze (Turcja) - Fü- } \\
\text { sun Baykal, Uniwersytet Ege, Turcja; Senem Yildiz, } \\
\text { Prywatna Turecka Kolegiata Izmir, Turcja } \\
\text { 4. Witamy w gospodarstwie: ankieta na temat potencjalnego } \\
\text { rozwoju agroturystyki w Indiach - Hemanth Peesapati } \\
\text { i Benedetto Rocchi, Uniwersytet Florencki, Włochy } \\
\text { 5. Agroturystyka w Kolumbii: między tradycja a innowacja } \\
\text { w kontekście zrównoważonego rozwoju - Margarita Mén- } \\
\text { dez, Uniwersytet Wschodniej Anglii, Wielka Brytania }\end{array}$ \\
\hline $\begin{array}{l}\text { Rola lokalnych produktów w agro- } \\
\text { turystyce: karpackie podejście } \\
\text { w zrównoważonym rozwoju ob- } \\
\text { szarów wiejskich (prezentacje i se- } \\
\text { sja world café) }\end{array}$ & $\begin{array}{l}\text { 1. Branding, marketing - Aleksandra Sikoraiova (SashaSi), } \\
\text { Sztuka i Rękodzieło Stiavnicy, Republika Słowacka } \\
\text { 2. Wspótpraca - Gabriela Elena Baciu, Rumuńskie Fo- } \\
\text { rum Górskie, Rumunia } \\
\text { 3. Rozwój - Gergely Horzsa, Uniwersytet Korwina, Bu- } \\
\text { dapeszt, Węgry }\end{array}$ \\
\hline
\end{tabular}


Tab. 1 (cd.)

\begin{tabular}{|c|c|}
\hline Sesja warsztatowa & Wygłoszone referaty \\
\hline \multicolumn{2}{|r|}{ Sesje równoległe $\mathrm{nr} 1$} \\
\hline $\begin{array}{l}\text { Przewodnictwo: } \\
\text { Ágnes Szabó-Diószeghy, mło- } \\
\text { dy ekspert Humtour LLC., } \\
\text { Węgry; Mátyás Szabó, pra- } \\
\text { cownik naukowy, Uniwersy- } \\
\text { tet Korwina w Budapeszcie, } \\
\text { Węgry; Tamara Mitrofanenko, } \\
\text { Sekretariat Konwencji Karpac- } \\
\text { kiej, UN Environment Wiedeń, } \\
\text { Austria }\end{array}$ & $\begin{array}{l}\text { 4. Produkty agroturystyczne i jedzenie - Víteslav Vítako- } \\
\text { cic, Stowarzyszenie Turystyki Wiejskiej i Rolniczej, } \\
\text { Republika Czeska } \\
\text { 5. Wyroby ręczne i przemystowe produkowane na mata skale } \\
\text { - Bernadetta Zawilińska, Uniwersytet Ekonomiczny } \\
\text { w Krakowie; Karpacka Rada Naukowa i Krzysztof } \\
\text { Szpara, Uniwersytet Technologii Informatycznych i Za- } \\
\text { rządzania w Rzeszowie, Karpacka Rada Naukowa, } \\
\text { Polska } \\
\text { 6. Środowisko i wymiary społeczne - Ágnes Szabó- } \\
\text {-Diószeghy, Humtour LLC., Węgry } \\
\text { 7. Trendy i prognozy - Mátyás Szabó, Uniwersytet Kor- } \\
\text { wina, Budapeszt, Węgry }\end{array}$ \\
\hline \multicolumn{2}{|r|}{ Sesje równoległe $\mathrm{nr} 2$} \\
\hline $\begin{array}{l}\text { Agroturystyka jako czynnik roz- } \\
\text { woju regionalnego } \\
\text { Przewodnictwo: } \\
\text { prof. Emilio Chiodo, Univer- } \\
\text { sity of Teramo, Włochy; prof. } \\
\text { Rita Salvatore, Stowarzysze- } \\
\text { nie ISLE, Francja }\end{array}$ & $\begin{array}{l}\text { 1. Agroturystyka i turystyczna oferta wsi: porównanie } \\
\text { Wtoch i Argentyny - Rita Salvatore, University of Te- } \\
\text { ramo, Włochy } \\
\text { 2. Agroturystyka i szlaki kulinarne - Lisa Chase, Univer- } \\
\text { sity of Vermont, USA; Mary Stewart, Oregon State } \\
\text { University, USA; David Gillespie, Canadian/American } \\
\text { Exchange, Kanada } \\
\text { 3. Możliwości spowolnienia migracji do miast z terenów } \\
\text { wiejskich poprzez wprowadzenie agroturystyki - Rohana } \\
\text { P. Mahaliyanaarachchi, Uniwersytet Sabaragamuwa } \\
\text { w Sri Lance, Sri Lanka } \\
\text { 4. Kapitał społeczny jako kluczowy czynnik sukcesu szla- } \\
\text { ków kulinarnych: społeczno-kulturowa perspektywa pro- } \\
\text { ducentów rolnych w Wiktorii (Australia) - Lukas Worth, } \\
\text { Monash University, Australia }\end{array}$ \\
\hline $\begin{array}{l}\text { Przewodnictwo: } \\
\text { Christian Hoffmann, starszy } \\
\text { pracownik naukowy, Instytut } \\
\text { Rozwoju Regionalnego, Eu- } \\
\text { rac Research, Włochy }\end{array}$ & $\begin{array}{l}\text { 1. Modele agroturystyczne w Azji odnoszace się do rozwoju } \\
\text { przedsiębiorczości na terenach wiejskich - Shaikh Tanveer } \\
\text { Hossain, Asian Productivity Organization, Japonia } \\
\text { 2. Agroturystyka jako narzędzie sprzyjajace zaangażowaniu } \\
\text { się młodzieży w rolnictwo i ekologiczna gospodarke na } \\
\text { rzecz wspierania rozwoju obszarów wiejskich - Felix Kwa- } \\
\text { bena Donkor, University of the Witwaterstrand- } \\
\text {-Johannesburg, Południowa Afryka } \\
\text { 3. Agroturystyka edukacyjna - studium przypadku obopól- } \\
\text { nych korzyści z regionalnej wspótpracy miejsko-wiejskiej } \\
\text { - Pier Angela Mozzi Muretto, współwłaścicielka } \\
\text { Agriturismo Alagna, Włochy; Rennen Zunder, pro- } \\
\text { jektant miejski, Kanada }\end{array}$ \\
\hline
\end{tabular}




\begin{tabular}{|c|c|}
\hline Sesja warsztatowa & Wygłoszone referaty \\
\hline \multicolumn{2}{|r|}{ Sesje równoległe $\mathrm{nr} 2$} \\
\hline $\begin{array}{l}\text { Agroturystyka w kontekście lokal- } \\
\text { nej perspektywy } \\
\text { Przewodnictwo: } \\
\text { dr Leah Joyner, University of } \\
\text { Utah, USA; dr Blanca Yagüe, } \\
\text { Universidad de Córdoba Espa- } \\
\text { ña i University of Utah }\end{array}$ & $\begin{array}{l}\text { 1. Propozycja łańcucha wartości dla miejsc agroturystycz- } \\
\text { nych - Luis Alberto Morales Zamorano, Autono- } \\
\text { miczny Uniwersytet Baja California, Meksyk } \\
\text { 2. Ekologiczna zielona herbata jako zasób agroturystyczny } \\
\text { - Assam w aspekcie wiedzy rdzennych mieszkańców: In- } \\
\text { die - Niranjan Das, Tezpur University, Indie } \\
\text { 3. Rola organizacji non-profit w lokalnej turystyce wiej- } \\
\text { skiej: przykłady z Japonii - Yasuo Ohe, Chiba Univer- } \\
\text { sity, Japonia } \\
\text { 4. Agroturystyka w Amazonii? Podejście do lokalnego sy- } \\
\text { stemu żywnościowego - Salomé Aramburo Calle, Na- } \\
\text { rodowe Parki Naturalne Kolumbii, Kolumbia }\end{array}$ \\
\hline $\begin{array}{l}\text { Obszary wiejskie i wielofunkcyj- } \\
\text { ne ustugi mające na celu popra- } \\
\text { wę jakości życia }\end{array}$ & $\begin{array}{l}\text { 1. Spersonalizowana i funkcjonalna żywność dla osób star- } \\
\text { szych: nowa ścieżka do wielofunkcyjnego rolnictwa - Filo- } \\
\text { mena Chiara, University of Foggia, Włochy } \\
\text { 2. Zwiększanie wielofunkcyjności w agroturystyce: niektóre } \\
\text { wyniki z projektu PROMETEA - Pietro Pulina w imie- } \\
\text { niu Fabia Madau, University of Sassari, Włochy } \\
\text { 3. Wykorzystywanie partnerstwa publiczno-prywatnego } \\
\text { w celu rozwoju zrównoważonej agroturystyki: studium przy- } \\
\text { padku Sao Toméi Principe - Michele Maccari, Włochy } \\
\text { 4. Agroturystyka: szansa na dywersyfikacjé i wielofunkcyjność } \\
\text { gospodarstw - Sofia Cei, Region Emilia-Romagna, } \\
\text { Włochy } \\
\text { 5. Rola agroturystyki w promowaniu aktywnego i zdrowe- } \\
\text { go starzenia się: nowa perspektywa turystyki społecznej } \\
\text { dla Europy - Matteo Rivezzi, Uniwersytet Foggia, } \\
\text { Włochy }\end{array}$ \\
\hline
\end{tabular}

Źródło: opracowanie własne na podstawie materiałów Eurac Research oraz tłumaczenia z języka angielskiego wykonanego w Ministerstwie Rolnictwa i Rozwoju Wsi.

W pierwszym dniu Kongresu w ramach sesji posterowej (odbywającej się w godzinach wieczornych), której przewodniczyła Jutta Staffler z Instytutu Rozwoju Regionalnego Eurac Research, uczestnicy mieli możliwość zapoznania się z przykładami dobrych praktyk w agroturystyce. Zaprezentowano ich siedem:

1. Agroturystyka, kreatywna klasa społeczna i nowi rolnicy w USA - R. David Lamie, Lori Dickes i Temitope Arogundade, Clemson University, USA;

2. Konceptualizacja ram programowych działań w agroturystyce - Lisa Chase, University of Vermont USA; Mary Stewart, Oregon State University, USA; 
3. Możliwości kształtowania relacji na płaszczyźnie rolnictwo-turystyka: "Seed Exchange Project" w Turcji - Durmus Seval, Gökçe Pekmezci, Mete Uğraş, Özlem Şahin, Ege University, Turcja;

4. Agroturystyka w Lesie Frankońskim - przykład regionalnej sieci rozwoju obszarów wiejskich - Klaus Schaumberg, Niemcy;

5. Rewitalizacja wsi: Agroturystyka i wykorzystanie historycznych budynków gospodarczych - Mike Mackay, Lincoln University, Nowa Zelandia; Harvey Perkins, University of Auckland, Nowa Zelandia; Tracy Nelson, AgResearch, Nowa Zelandia;

6. Aktualny stan rozwoju agroturystyki w Wietnamie - Trinh Thi Thu Thao, New Zealand Tourism Research Institute, Auckland University of Technology, Nowa Zelandia;

7. Zarzadzanie przez rdzenna wspólnote wiejska, rola prywatnego i publicznego sektora. Przyktady z Ameryki Łacińskiej i argentyńskiej organizacji: The Argentine Network of Rural Community Tourism (RATuRC) - Ramiro Ragno, Latin America Cases i Argentine Network of Rural Community Tourism RATURC, sekretarz ds. Rolnictwa Rodzinnego SAF, Fundación Buenavida, Argentyna.

Spośród prezentowanych posterów wyróżnienie otrzymały Lisa Chase i Mary Stewart z USA, które przedstawiły zagadnienie konceptualizacji ram programowych działań podejmowanych $w$ branży agroturystycznej. $\mathrm{W}$ swojej prezentacji autorki wyjaśniły, że $\mathrm{w}$ ramy koncepcyjne pojęcia "agroturystyka" wpisują się: dwa poziomy - podstawowy i peryferyjny, a także pięć kategorii działalności agroturystycznej, takich jak: sprzedaż bezpośrednia, edukacja, noclegi, rekreacja na świeżym powietrzu oraz rozrywka. Za pomocą schematu autorki objaśniły, jakie działania agroturystyczne zaliczają do poziomu podstawowego, a jakie do peryferyjnego. Celem wykorzystania posteru było otworzenie debaty nad pojmowaniem agroturystyki, której znaczenie w USA stale rośnie. Na schemacie (w formie koła) zostały zobrazowane różne sposoby rozumienia agroturystyki (zob. Chase, Stewart, Schilling, Smith, Walk, 2018). Pokazano, że niektórzy utrzymują, iż agroturystyka odbywa się na terenie funkcjonującego gospodarstwa rolnego (działania na poziomie podstawowym, umieszczone w wewnętrznej części koła), a inni zaliczają do niej również gospodarstwa nieprodukcyjne rolniczo oraz takie wydarzenia, jak targi rolnicze czy jarmarki. Jeszcze inni stawiają pytanie: czy czynności w gospodarstwach, które mają niewiele wspólnego z rolnictwem (działania na poziomie peryferyjnym, umieszczone w zewnętrznej części koła), np. organizacja wesel i zajęcia rekreacyjne na świeżym powietrzu (np. kolarstwo górskie), można 
zakwalifikować do agroturystyki? Autorki uznały, że „autentyczna agroturystyka” to taka, która daje "możliwość dywersyfikacji dochodów rolniczych poprzez podejmowanie działalności turystycznej na terenie gospodarstwa, w celu uzupełnienia niskich dochodów z rolnictwa. Pomaga utrzymać rentowność czynnych gospodarstw rolnych, wspiera i promuje zasoby rolnicze oraz tradycję i kulturę obszarów wiejskich". Prelegentki podkreśliły, że agroturystyka to udany przykład zrównoważonej turystyki, która na przestrzeni lat zyskała na znaczeniu.

W drugim dniu Kongresu sesję plenarną poświęcono rozwojowi agroturystyki w wybranych krajach świata. Obrady otworzył Pandurang Taware, szef Agri Tourism Development Organization w Indiach, wygłaszając referat pt. Agroturystyka w Indiach. Prelegent podkreślił, że rolnictwo stanowi podstawę gospodarki indyjskiej. Około $85 \%$ populacji tego kraju jest bezpośrednio lub pośrednio zależna od rolnictwa, z którego pochodzi niemal 26\% indyjskiego PKB. Turystyka jest rozumiana jako instrument służący do generowania zatrudnienia, zmniejszania ubóstwa i wspierania zrównoważonego rozwoju społeczeństwa. Czynniki te określają rolę agroturystyki i wyzwania, które będą przed nią stały w Indiach. Referent zaznaczyl, że jedną z zalet agroturystyki jest to, że sytuuje ona sektor rolniczy blisko branży turystycznej. W Indiach oczekuje się, że będzie to korzystne dla obu sektorów. Agroturystykę w tym kraju wiąże się także z działaniami prozdrowotnymi mieszkańców miast i naturoterapią (wykorzystywanie ziół i przyrody w lecznictwie).

Następnie Jacqui Taylor, szefowa Agritourism South Africa, wystąpiła z prezentacją pt. Agroturystyka w Afryce. Na początku prelegentka zwróciła uwagę na specyficzność agroturystyki afrykańskiej, wynikającą z uwarunkowań geograficznych kontynentu oraz cech społecznych mieszkającej na nim ludności. Zaznaczyła, że użytki rolne zajmują jedynie $30 \%$ powierzchni Afryki. W większości są to naturalne pastwiska, niekiedy uprawiane przy niskim stopniu mechanizacji, a wykorzystywane do ekstensywnego chowu zwierząt, których nie można spotkać nigdzie indziej na świecie. Istnieją również wielkoobszarowe gospodarstwa, czyli plantacje, na których uprawia się m.in.: kakaowce, kauczukowce, kawowce, przyprawy, palmy olejowe oraz bawełnę. Referentka podkreśliła, że kontynent afrykański jest odwiedzany przez naukowców, badaczy i ludzi ciekawych jego kultury i przyrody. Zaznaczyła, że zjawisko agroturystyki $\mathrm{w}$ Afryce jest stosunkowo nowym zagadnieniem, kojarzonym nie tyle z zabudowaniami rolnymi, co $\mathrm{z}$ pracą $\mathrm{w}$ gospodarstwie oraz obcowaniem $\mathrm{z}$ jego właścicielami. Mając jednak na uwadze rozwój agroturystyki jako sektora 
gospodarki na kontynencie afrykańskim, 20 września 2016 r. stworzono organizację pozarządową o nazwie Agritourism South Africa, ustanowioną $\mathrm{w}$ celu promowania zrównoważonego rozwoju obszarów wiejskich w Afryce Południowej. Zadaniem tej organizacji jest ukonstytuowanie grupy społecznej, złożonej z rolników i mieszkańców wsi, tak, aby mogli oni realizować kampanie (działania) agroturystyczne, przyczyniając się do sprawiedliwej dystrybucji zasobów. Organizacja stara się poprzez agroturystykę i inne procesy związane z rolnictwem łączyć wiejskie społeczności, rolników i pracowników rolnych. Wymienione trzy grupy społeczne są ze sobą wzajemnie powiązane i zależne od siebie. Prelegentka zaznaczyła, że zastosowanie technologii $\mathrm{w}$ rolnictwie afrykańskim skutkuje stopniową redukcją liczby pracowników zatrudnionych w tym sektorze i koniecznością przekwalifikowywania ich. W tej sytuacji agroturystykę można postrzegać jako szansę dla tych osób.

W sesji plenarnej drugiego dnia Kongresu jako ostatnia wystąpiła prof. Karina Toledo Solha z University of São Paulo w Brazylii, z prezentacją pt. Agroturystyka w środowisku wiejskim Brazylii. Prelegentka najpierw przekazała kilka istotnych informacji o Brazylii, podkreślając, że jest to kraj przemysłowo-rolniczy, jeden z lepiej rozwiniętych w Ameryce Południowej, gdzie gospodarka opiera się głównie na usługach. Rolnictwo stanowi jedynie 6\% PKB tego państwa. Następnie zaznaczyła, że agroturystyka $\mathrm{w}$ Brazylii jest rozumiana jako dziedzina równoznaczna $\mathrm{z}$ turystyką wiejską. Turystykę wiejską, zgodnie z definicją z 2008 r. stworzoną przez brazylijskie Ministerstwo Turystyki, pojmuje się jako zbiór działań turystycznych związanych z produkcją rolniczą, zwiększających wartość produktów rolnych i towarzyszących im usług, przyczyniających się ponadto do zachowania na terenach wiejskich dziedzictwa kulturowego i przyrodniczego. Geneza agroturystyki w Brazylii sięga 1984 r., kiedy podjęto działania na rzecz podniesienia jakości produktów i usług turystycznych. Prelegentka podkreśliła, że na rozwój turystyki wiejskiej ma wpływ wymiar terytorialny kraju oraz jego zróżnicowanie regionalne. Zaznaczyła, że bardzo ważne jest wspieranie, a przez to wzmacnianie agroturystyki, przed którą stoją obecnie różne wyzwania. Do osiągnięcia tego celu niezbędne są: współpraca między różnymi sektorami gospodarki, a także czerpanie wiedzy z doświadczeń i mądrości starszych mieszkańców wsi.

W drugim dniu Kongresu odbyły się również sesje warsztatowe, których tematykę zaprezentowano $\mathrm{w}$ tab. 2. 
Tab. 2. Sesje warsztatowe w drugim dniu Kongresu (8 listopada 2018 r.)

\begin{tabular}{|c|c|}
\hline Sesja warsztatowa & Wygłoszone referaty \\
\hline \multicolumn{2}{|r|}{ Sesje równoległe $\mathrm{nr} 3$} \\
\hline $\begin{array}{l}\text { Agroturystyka - globalny feno- } \\
\text { men } \\
\text { Przewodnictwo: } \\
\text { prof. Adriano Ciani, Univer- } \\
\text { sity of Perugia, Włochy }\end{array}$ & $\begin{array}{l}\text { 1. Agroturystyka: dlaczego należy ja badać, chronić } \\
\text { i promować na świecie - Adriano Ciani, Biosphera } \\
\text { Scientific and Cultural Association, Włochy } \\
\text { 2. Agroturystyka w „cieptym sercu” Afryki. Malawi - Fide- } \\
\text { lis Chasukwa Mgowa, Mazizi Agritourism Farm, } \\
\text { Malawi } \\
\text { 3. Agroturystyka w Austrii - Erika Quendler, Federal- } \\
\text { ny Instytut Ekonomiki Rolnictwa, Austria } \\
\text { 4. Potencjat rozwoju agroturystyki w Nepalu: studium } \\
\text { przypadku wioski Phikuri - Kumar Bhatta, Chiba Uni- } \\
\text { versity, Japonia } \\
\text { 5. Agroturystyka w Szkocji - Caroline Millar, Go-Rural, } \\
\text { Szkocja, Wielka Brytania }\end{array}$ \\
\hline $\begin{array}{l}\text { Różnorodność działań agrotury- } \\
\text { stycznych - wybrane trendy i do- } \\
\text { bre praktyki } \\
\text { Przewodnictwo: } \\
\text { Thomas Dax, zastępca dyrek- } \\
\text { tora Federalnego Instytutu na } \\
\text { rzecz Obszarów o Niekorzyst- } \\
\text { nych Warunkach Gospoda- } \\
\text { rowania i Terenów Górskich, } \\
\text { Niemcy }\end{array}$ & $\begin{array}{l}\text { 1. Agroturystyka w Japonii: studium przypadku Wazuki } \\
\text { w Kioto - Midori Goso, Teikyo University, Japonia } \\
\text { 2. Badania w zakresie rozwoju agroturystyki w Maharashtra: } \\
\text { model zrównoważonego rozwoju - Girish Mude, MIT } \\
\text { School of Management, Indie } \\
\text { 3. Szlak agroturystyki kulinarnej na wschodzie Tajlandii } \\
\text { - Natthakan Pruksorranan, Burapha University, } \\
\text { Tajlandia } \\
\text { 4. Turystyka społeczna jako szansa wzmocnienia zrówno- } \\
\text { ważonej turystyki - strategie agroturystyki w regionach } \\
\text { górskich Gruzji - Lela Khartishvili, Tbilisi State Uni- } \\
\text { versity, Gruzja } \\
\text { 5. Stowarzyszenie winiarzy - turystyka winiarska i jej } \\
\text { efekty społeczno-ekonomiczne w dwóch środkowoeuropej- } \\
\text { skich regionach wina - Thomas Dax w imieniu Ne- } \\
\text { mesa Gusztáva, Węgierska Akademia Nauk, Węgry }\end{array}$ \\
\hline $\begin{array}{l}\text { Przewodnictwo: } \\
\text { prof. Carla Barbieri, Uniwer- } \\
\text { sytet Stanowy Karoliny Pół- } \\
\text { nocnej, USA }\end{array}$ & $\begin{array}{l}\text { 1. Rewitalizacja wiejskich miejscowości oraz regionalnych } \\
\text { miast na Wyspie Potudniowej Nowej Zelandii: ważna } \\
\text { i rosnaca rola agroturystyki - Harvey Perkins, Univer- } \\
\text { sity of Auckland, Nowa Zelandia } \\
\text { 2. Agroturystyka szansa w dostosowywaniu się do zmian } \\
\text { klimatycznych na Sri Lance - Rohana P. Mahaliyana- } \\
\text { rachchi, Uniwersytet Sabaragamuwa w Sri Lance, } \\
\text { Sri Lanka } \\
\text { 3. Wiejskie krajobrazy, dziedzictwo kulturowe i agrotury- } \\
\text { styka: analiza porównawcza obszaru płaskowyżu Atherton } \\
\text { i podnóża śródladowej części centralnej Wenecji - Bruce } \\
\text { Prideaux, Central Queensland University, Australia; } \\
\text { Francesco Vallerani i Francesco Visentin, Ca' Foscari } \\
\text { University of Venice, Włochy; Michelle Thompson, } \\
\text { Central Queensland University, Australia }\end{array}$ \\
\hline
\end{tabular}


Tab. 2 (cd.)

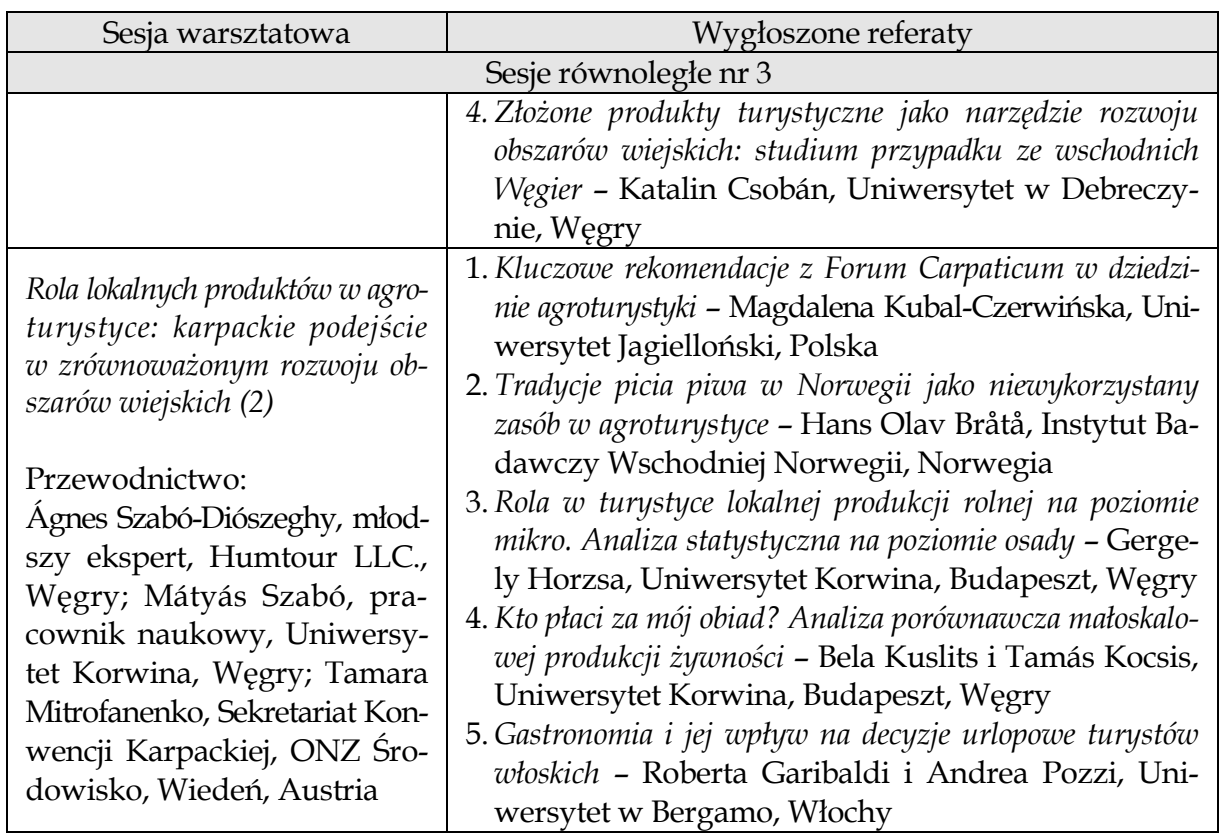

Źródło: opracowanie własne na podstawie materiałów Eurac Research oraz tłumaczenia z języka angielskiego wykonanego w Ministerstwie Rolnictwa i Rozwoju Wsi.

W godzinach popołudniowych uczestnicy Kongresu wzięli udział w wizytach studyjnych w okolicznych gospodarstwach agroturystycznych oraz innych obiektach turystyki wiejskiej, funkcjonujących w Południowym Tyrolu w ramach marki Roter Hahn, o której wspomniano na wstępie.

Trzeciego dnia Kongresu (9 listopada) podczas ostatniej sesji plenarnej poświęconej w dalszej części agroturystyce na świecie jako pierwszy wystąpił z referatem Pietro Schipani z Ministerstwa Polityki Rolnej, Żywnościowej i Leśnej oraz Turystyki we Włoszech. W prezentacji pt. Włochy, ojczyzna agroturystyki między różnorodnościq a doskonatościq przedstawił agroturystykę jako najlepszą drogę do docenienia włoskiej wsi. Agroturystyka rozwija się we Włoszech już od 30 lat, a jej ważną oraz unikatową cechą jest to, że mogą ją prowadzić rolnicy, wyłącznie w gospodarstwach rolnych. W języku włoskim słowo agriturismo używane jest zarówno w odniesieniu do zjawiska turystyki w kraju, jak i do samego gospodarstwa agroturystycznego. Dzięki gospodarstwom agroturystycznym, których obecnie jest we Włoszech ponad 23,4 tys., udało się uratować znaczną liczbę cennych historycznie budynków gospodarczych i zacho- 
wać tradycyjne rolnictwo w miejscach, w których panują trudne warunki do uprawy roślin. Znaczny odsetek włoskich gospodarstw agroturystycznych znajduje się na obszarach pagórkowatych i górzystych, gdzie nie można na dużą skalę rozwinąć rolnictwa wymagającego rozległych terenów dla silnie zmechanizowanych sposobów produkcji. Agroturystyka we Włoszech sprzyja jej tradycyjnym metodom, a także integracji ze środowiskiem naturalnym (lasy, zarośla śródziemnomorskie) i kulturowym (bliskość kultury i sztuki miast oraz wsi). W gospodarstwach agroturystycznych goście mają możliwość obserwowania z bliska miejsc, w których powstawała i rozwijała się sztuka włoska i które wciąż zachowują wiele skarbów dla zwiedzających. W związku z tym włoskie gospodarstwa tego typu podlegają określonym regułom. Poświęca się tam więcej czasu na działalność rolniczą niż turystyczną. Gościom serwuje się własne produkty spożywcze, oferuje się wyroby i usługi wynikające z działalności rolniczej i dostosowane do specyfiki działania danego gospodarstwa. Gospodarzy obowiązują ograniczenia w ponownym wykorzystaniu budynków oraz w możliwości pozyskania usług / pracy zewnętrznej. Pietro Schipani zaznaczył, że taki rozwój agroturystyki we Włoszech nie byłby możliwy, gdyby nie wdrożenie systemowych rozwiązań publicznych, począwszy od szczebla ogólnokrajowego, a na gminnym/miejskim skończywszy. W 2006 r. działalność agroturystyczna została określona prawnie (zob. Ministero delle politiche agricole alimentari, forestali e del turismo), a od 2013 r. budowana jest ogólnokrajowa marka włoskiej agroturystyki (zob. Agriturismo Italia).

Następnie uczestnicy wysłuchali wystąpienia zatytułowanego Agroturystyka w USA i Kanadzie: co już wiemy a czego jeszcze nie wiemy, które przygotowała prof. Carla Barbieri z Uniwersytetu Stanowego Karoliny Północnej w USA. Na wstępie swojej wypowiedzi badaczka zaznaczyła, że konieczność zwiększenia dochodów rolników i rosnące zainteresowanie nawiązaniem kontaktów z lokalnymi producentami żywności w ciągu ostatnich kilku dekad przyczyniły się do stałego rozwoju agroturystyki w USA i Kanadzie. Miało to z kolei wpływ na rozwój prac naukowych zmierzających do poszerzenia wiedzy i wzmocnienia praktyki w zakresie agroturystyki. Prelegentka wskazała na trzy główne konteksty oddziaływania agroturystyki:

- działalność agroturystyczna stanowi dodatkowe obciążenie dla rolnika i gospodarstwa rolnego (biznes i rodzina), zatem może mieć wpływ na spadek zamożności i dobrostan członków jego rodziny; 
- agroturystykę powinno się doceniać z uwagi na różnorodność usług oferowanych turystom, a zwłaszcza takich, które wychodzą poza zakres rekreacji, np. ochrona zasobów naturalnych i kulturowych;

- kobiety odgrywają kluczową rolę w prowadzeniu działalności agroturystycznej, to one stoją przed szeregiem wyzwań na drodze do odniesienia sukcesu. Poza rozpoznaniem tych wyzwań, istotne jest, w jaki sposób kobiety poradzą sobie z nimi i jak wykorzystają społeczne możliwości osiągnięcia sukcesu zawodowego i w życiu osobistym.

Zdaniem prelegentki dostępną wiedzę o agroturystyce należy uznać za niewystarczająca, co ma wpływ na jej dalszy rozwój. Właśnie z tego powodu badaczka uważa, że należy dzielić się wiedzą i informacjami na temat dobrych praktyk, aby wzmacniać branżę agroturystyczną.

W sesji plenarnej jako ostatni wystąpił Mu Xingzenga, szef Akademii Nauk Społecznych Hebei w Chinach. W referacie pt. Agroturystyka w Chinach zauważył on, że zintegrowany rozwój rolnictwa i turystyki w Chinach wciąż znajduje się w początkowej fazie. Prowincja Hebei, obejmująca dwie metropolie, tj. Pekin i Tianjin, charakteryzuje się klasyczną gospodarką, znajduje się ona jednak również $\mathrm{w}$ centrum trzeciego bieguna wzrostu chińskiej gospodarki, jakim jest tzw. Nowy Obszar Xiong'an. Prelegent wysunął wniosek, że wykorzystanie rolnictwa w celach rekreacyjnych w tej prowincji ma referencyjną i pouczającą wartość.

Główną myślą przewodnią drugiej części sesji plenarnej był marketing agroturystyki, analizowany na poziomie regionalnym i ogólnokrajowym. Pierwszym tego przykładem był referat pt. Model agroturystyczny "Red Rooster" w Południowym Tyrolu, wygłoszony przez Hansa J. Kienzla, przedstawiciela Red Rooster (Wakacje na farmie w Południowym Tyrolu) oraz Związku Rolników Południowego Tyrolu we Włoszech. Referent mówił o historii turystyki wiejskiej w tym regionie i wprowadzeniu marki parasolowej Roter Hahn. Wyjaśnil, jak została ona opracowana i wprowadzona w życie oraz jak ewoluowała oferta wakacji w gospodarstwach rolnych $\mathrm{w}$ tym regionie. Odniósł się do sposobu promowania marki również na rynkach zagranicznych. Zaznaczył, że od 2014 r. marka Roter Hahn jest reprezentowana $w$ mediach społecznościowych, takich jak: Facebook, Instagram, YouTube i Pinterest, dzięki czemu mogą ją śledzić użytkownicy $\mathrm{z}$ całej Europy. Obecnie nacisk kładzie się na marketing miejsc noclegowych w sezonie zimowym. Wyposażenie gospodarstwa, śniadania i marketing produktów rolnych z własnego gospodarstwa, jak również kontakt $\mathrm{z}$ rodziną goszczącą odgrywają decydującą rolę w promocji oferty turystycznej w sezonie zimowym. 
O promocji agroturystyki mówił również Umberto Selmi z Włoskiego Instytutu Usług dla Rynku Rolnego i Spożywczego (ISMEA) w wystąpieniu pt. Przeglad logotypów i systemów klasyfikacji jakości w agroturystyce. Prezentacja ta stanowiła uszczegółowienie wspomnianego już wcześniej wystąpienia Pietra Schipaniego, przedstawiciela administracji rządowej we Włoszech. Począwszy od 2013 r. Włochy wykorzystują sektorowy znak towarowy Agriturismo Italia (zob. Agriturismo Italia), któremu towarzyszy nowy system klasyfikacji (kategoryzacji) gospodarstw oznakowanych symbolem słonecznika. Znak ten wyróżnia gospodarstwa regularnie prowadzące działalność agroturystyczną zgodnie z obowiązującymi przepisami. Warto tu nadmienić, że we Włoszech odmiennie niż w Polsce działalność rolnicza jest działalnością gospodarczą i podlega rejestracji. Podobnie jak w przypadku hoteli, włoska klasyfikacja gospodarstw agroturystycznych ma na celu przybliżenie użytkownikom ogólnego poziomu ich komfortu, różnorodności oferowanych usług (w tym wyżywienia) oraz jakości środowiska naturalnego (przyrody, krajobrazu, ciszy). Aby zbudować system klasyfikacji, włoskie Ministerstwo Rolnictwa we współpracy z regionalnymi i krajowymi stowarzyszeniami agroturystycznymi rozpoczęło realizację szeroko zakrojonego projektu badawczego. Jego celem była m.in. ocena potrzeb turystów włoskich i zagranicznych w zakresie agroturystyki. W projekcie wzięto pod uwagę cechy, które najlepiej odpowiadają potrzebom i pragnieniom turystów, oraz określono poziom ważności tych cech. Efektem badań było opracowanie punktowego systemu klasyfikacji gospodarstw w skali od jednego do pięciu słoneczników. Przyjęto, że wymogi tego systemu mają obowiązywać w całym kraju, jednak urzędnicy pracujący $w$ administracjach regionalnych mogą dostosować te normy do lokalnego kontekstu agroturystycznego. Dotyczy to takich kwestii, jak: formy produkcji rolnej, rodzaje hotelarstwa, wielkość przedsiębiorstwa i systemu produkcyjnego, cechy charakterystyczne dla krajobrazu lub lokalne zwyczaje i tradycje. Wypracowany system kategoryzacji gospodarstw stanowi gwarancję dla uwzględniania cech regionalnych.

Na koniec Kongresu odbyły się dyskusja oraz podsumowanie obrad. Pytań i wypowiedzi było wiele. Organizatorzy usłyszeli słowa pochwały oraz podziękowań. Zaprezentowane podczas Kongresu referaty uświadomiły uczestnikom, że agroturystyka jest bardzo szerokim pojęciem i że można ją postrzegać oraz definiować na wiele sposobów. Zgodzono się, że agroturystyka oferuje turystom specyficzne dla gospodarstw rolnych doświadczenia, związane z rolnictwem. Uznano, że jest to dochodowa 
działalność mieszkańców obszarów wiejskich, która opiera się na ich kreatywności oraz innowacyjności stosowanych rozwiązań, przy jednoczesnym wykorzystaniu lokalnych zasobów dziedzictwa kulturowego i przyrodniczego. Podkreślono, że istotne znaczenie mają bezpośrednie i rodzinne powiązania rolnika z gośćmi. Podczas Kongresu poruszono wiele wątków tematycznych, wszystkie skłaniają do przemyśleń, a zwłaszcza te, które odnoszą się do czynników administracyjnych i społecznych oddziałujących na agroturystykę.

Uczestnicy Pierwszego Światowego Kongresu Agroturystyki wyrazili nadzieję, że stanie się on przyczynkiem do dyskursu międzynarodowego poświęconego poruszonej w Bolzano problematyce, a efektem tych obrad będzie spójność pojmowania i definiowania agroturystyki.

\section{Bibliografia}

Agriturismo Italia. Pobrane z: http:/ / www.agriturismoitalia.gov.it/en/home (12.01.2019).

Eurac Research. Pobrane z: http://www.eurac.edu/en/pages/default.aspx (12.01.2019).

Chase, L.C., Stewart, M., Schilling, B., Smith, B., Walk, M. (2018). Agritourism: toward a conceptual framework for industry analysis. Pobrane z: https://www.foodsystemsjournal. org/index.php/fsj/article/view/572 (12.01.2019).

Ministero delle politiche agricole alimentari, forestali e del turismo. Pobrane z: https://www. politicheagricole.it/flex/cm/pages/ServeBLOB.php/L/IT/IDPagina/6012 (12.01.2019).

Roter Hahn. Pobrane z: www.roterhahn.pl (12.01.2019). 